\title{
Tissue mRNA expression in rat of newly described matrix metalloproteinases
}

\author{
FABIÁN BERNAL, HANS-PETER HARTUNG and BERND C. KIESEIER
}

Department of Neurology, Research Group for Clinical and Experimental Neuroimmunology, Heinrich-HeineUniversity, Düsseldorf, Germany

\begin{abstract}
Matrix metalloproteinases (MMPs) comprise a large group of endoproteinases that degrade all protein components of the extracellular matrix. Functionally, MMPs contribute to several different physiological as well as pathological conditions. The number of newly described MMPs has increased in recent years, although current knowledge about their expression pattern in various tissues remains incomplete. Here we analyzed the relative mRNA expression of the most recently described MMPs - MT5-MMP (MMP-24), MT6MMP (MMP-25), MMP-27 and epilysin (MMP-28) - in a broad selection of rat tissues using real time-PCR. MMP-24 mRNA was found to be widely expressed with predominance in the central nervous system. MMP25 mRNA, in contrast, exhibited peak expression levels in testis, kidney and skeletal muscle, differing from previously described distribution patterns in humans. mRNAs for MMP-27 and MMP-28 were generally expressed at a lower level. All four MMPs studied were detected at higher mRNA levels in bone and kidney, suggesting a possible role of these MMPs in physiological processes within these two organs. The present study highlights the differential distribution pattern of newly described MMPs among different tissues and underlines differences in the mRNA expression between different species.
\end{abstract}

Key terms: bone, CNS, epilysin, kidney, MT5-MMP, MT6-MMP, testis.

Matrix metalloproteinases (MMPs) represent a large family of zinc-dependent endoproteinases that have become focus of intensive research in recent years due to their relevant functional implication in both physiological and pathological processes. Based on their ability to degrade nearly all extracellular matrix (ECM) components, MMPs are considered to be key enzymes in processes that imply tissue development, tissue remodeling or cell migration (Yong et al., 2001; Nagase and Woessner, 1999). Five new members of the MMP family have been identified in recent years -MMP-24 through MMP-28- and were first described in human tissue, with rat counterparts for all except MMP-26 (Puente and LópezOtín, 2004). However, studies on their expression have been focused on human cell lines and on few pathological conditions. Little attention has been devoted to their expression pattern in experimental animals; the majority of the data available to date is for mouse. The aim of the present study was to define the RNA expression pattern of these newly described MMPs in rat tissues, since many experimental models in physiology research are conducted in rat strains. Thus, the following MMPs were studied: MT5-MMP (MMP-24) (Llano et al., 1999), MT6-MMP (MMP-25) (Pei, 1999; Velasco et al., 2000), MMP-27 (Clark et al., 2003) and epilysin (MMP-28) (Lohi et al., 2001; Marchenko and Strongin, 2001).

Three adult Lewis rats were killed by ether overdose, and tissues were quickly removed and flash frozen in liquid nitrogen, including adipose tissue, femoral bone, skeletal muscle, heart, lung, kidney, small intestine, spleen, testis, uterus, ovary, placenta, spinal cord, brainstem, 
cerebellum, cortex and forebrain. In addition, one E15 total fetal brain was also obtained and frozen. All samples were stored at $-70{ }^{\circ} \mathrm{C}$ until use. Tissue total RNA was extracted using TRIzol ${ }^{\circledR}$ (Invitrogen, Karlsruhe, Germany) and reverse transcription (RT; Applied Biosystems, Branchburg, New Jersey, USA) was performed according to manufacturer's instructions. Complementary DNA was stored at $4^{\circ} \mathrm{C}$ until its use.

Primer pairs for the selected genes were designed with Primer Express ${ }^{\circledR}$ software (Applied Biosystems) using the rat mRNA sequence for MMP-24 as published and the predicted ones for the other MMPs (Table I). Predicted mRNA sequences were automatically generated by the National Center for Biotechnology Information (NCBI) using existent genomic sequences, gene prediction method GNOMON and supported by mRNA evidences (http: // www.ncbi.nlm.nih.gov/genome/guide/ gnomon.html ). The GAPDH gene was selected as a housekeeping gene to normalize variations in cDNA content. Primers were designed to include an intron in the amplicon sequence to avoid both genomic DNA and immature mRNA interferences, so it can be accepted that results reflect the mature mRNA pool in each tissue. SYBR ${ }^{\circledR}$ Green PCR Master Mix (Applied Biosystems) was used as reaction medium in a total volume of $30 \mu \mathrm{l}$. Real time-PCR reactions were performed in an ABI Prism 7000 Sequence Detection System (Applied Biosystems). The precycling steps were $2 \mathrm{~min}$ at $50^{\circ} \mathrm{C}$ and 10 min at $95^{\circ} \mathrm{C}$, followed by $15 \mathrm{~s} 95^{\circ} \mathrm{C}$ and 1 $\min 60^{\circ} \mathrm{C}$ for 45 cycles. At the end of the thermal cycles a dissociation protocol was performed, starting at $60^{\circ} \mathrm{C}$ and measuring fluorescence with $0.5^{\circ} \mathrm{C}$ increments, to ensure that a single product was detected for each primer pair. An automatic threshold over background was selected, and the cycle corresponding to its surpass $(\mathrm{Ct})$ was defined. For each reaction, $\mathrm{Cts}$ for different MMPs were normalized with the corresponding GAPDH $\mathrm{Ct}$ by substraction $(\Delta \mathrm{Ct})$.

Relative tissue mRNA expression levels for the different MMPs studied are shown in Figure 1. In general, MMP-24 and, in smaller amounts, MMP-25 mRNAs were expressed at detectable levels in most of the tissues investigated, while mRNA expression levels for MMP-27 and especially MMP-28 were found to be more restricted.

TABLE I

Gene expression analyzed by real time-PCR and primer sequences used for it.

\begin{tabular}{lccll}
\hline Gene Name & Other name & Genebank Access Number & & Primer sequence \\
\hline MMP-24 & MT5-MMP & NM_031757 & Forward & TGCAACAGTTTTACGGGATCC \\
& & & Reverse & TTGTCGTCTGGTCCAACACAC \\
MMP-25 & MT6-MMP & XM_220199 & Forward & GGTGTTCCAGGAACGACAGC \\
& & Reverse & AATTCTACCAGTGGCCTCGCT \\
MMP-27 & & XM_235795 & Forward & TGTCTTGCCTGGTTACCCCA \\
& & Reverse & CGTCTTGGAAACCCGAGTGT \\
MMP-28 & Epilisyn & XM_220785 & Forward & TGTACGGAAAGCCCCTAGA \\
& & Reverse & TCTTTCCAGGGAGTTGGGTG \\
GAPDH & & NM_017008 & Forward & GAACGGGAAGCTCACTGGC \\
& & & Reverse & GCATGTCAGATCCACAACGG \\
\hline
\end{tabular}




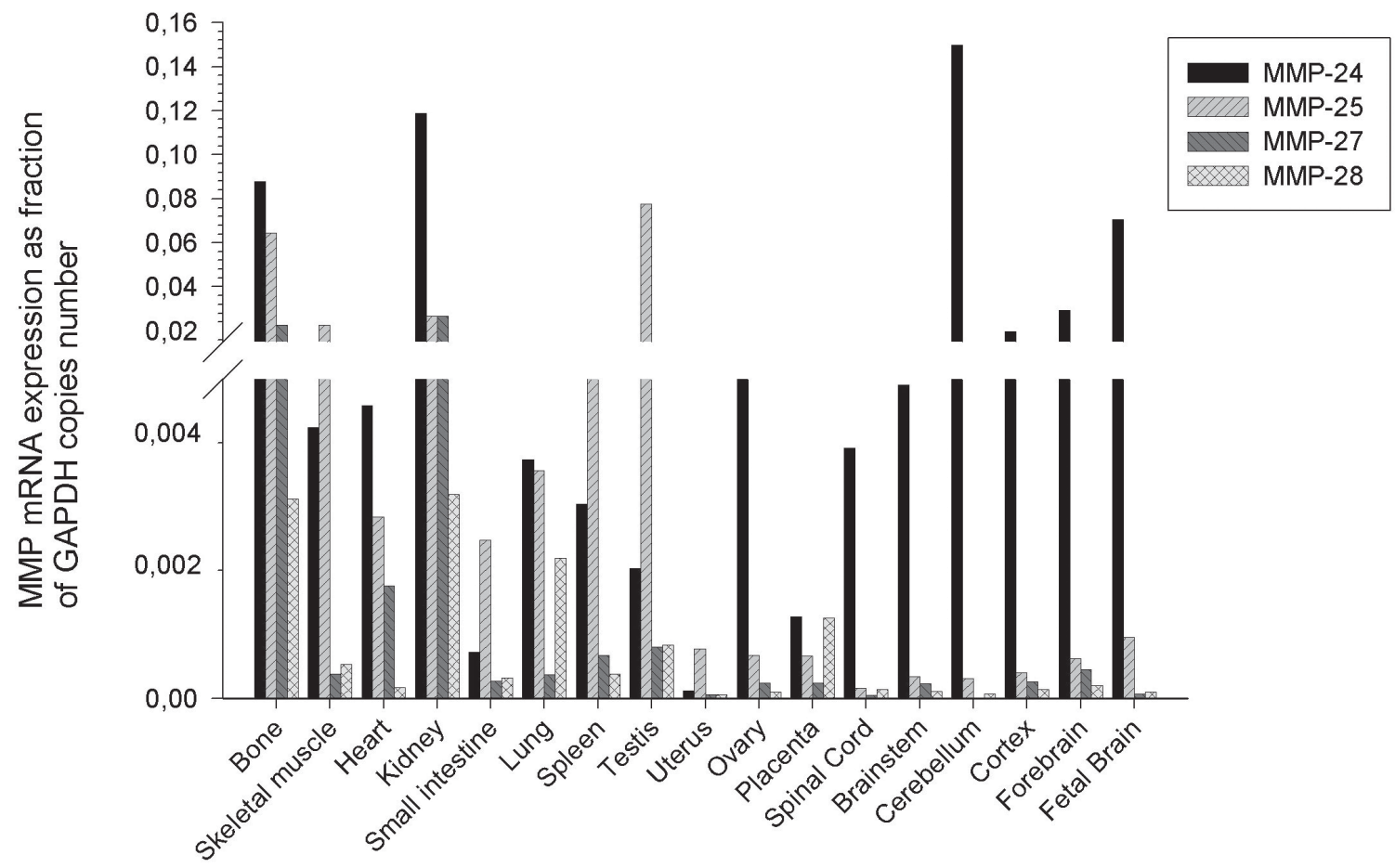

Figure 1. Distribution and expression patterns of newly described MMPs mRNA in rat. Relative expression for each MMP with respect to the housekeeping gene GAPDH. Relative values are $2^{-(\Delta \mathrm{Ct})}$, indicating the fraction of total GAPDH mRNA copies corresponding to the different MMPs studied.

MMP-24 is a membrane-bound MMP with a short cytoplasmic domain and closely related to the MMP-14 (MT1-MMP) group. In the present study, mRNA levels of this MMP were found to be expressed at the highest levels in the central nervous system CNS especially in the cerebellum, as well as in fetal rat brain. After cDNA normalization other tissues showed comparable MMP-24 mRNA expression levels, such as in bone and kidney. Our observations in the CNS are in line with previous reports of high MMP-24 expression in the rodent brain (Jaworski, 2000; Sekine-Aizawa et al., 2001; Nuttall et al., 2004). There are, however, some discrepancies with previous observations in rat since no remarkable mRNA expression of MMP-24 has been detected in lung or kidney before (Jaworski, 2000; SekineAizawa et al., 2001). This discrepancy is most likely based on technical differences; we used real time RT-PCR and an end-point strategy with more than 40 cycles, whereas in other studies Northern blot and in situ hybridization were applied.

We believe that the technical approach chosen in our study may ensure the detection of even low amounts of specific mRNA. The general tissue expression pattern of MMP-24 mRNA in rat matches to some degree with the one described in human tissues, where it has been detected in brain, kidney and pancreas (Romanic et al., 2001). MMP-24 is able to activate gelatinase A (MMP-2) (Llano et al., 1999) and primarily acts on proteoglycans (Wang and Pei, 2001). Proteoglycans, mainly chondroitin sulfate, are a major component of the osseous protein matrix, and therefore the detection of high expression levels of MMP-24 mRNA in bone suggests a critical role of this protease in the dynamic balance between bone formation and destruction. A potential relevant function of MMP-24 in the CNS may be related to the inhibitory role of proteoglycans in axonal and dendritic extension (Hayashita-Kinoh et al., 2001). 
In contrast to other members of the MTMMP group, MMP-25 lacks the cytoplasmic domain and is anchored to membrane glycosylphosphatidilinositol (Kojima et al., 2000). MMP-25 mRNA was detected at high levels in bone and kidney, but also in muscle, lung and spleen. The highest mRNA expression levels were detectable in testis. When first described in humans (Pei, 1999; Velasco et al., 2000), MMP-25 was defined as highly expressed in brain tumors and leukocytes and lacking in most of the other tissue analyzed. Our observation of MMP-25 mRNA in the spleen probably reflects the presence of leukocytes within this tissue. Our defined expression profile appears similar to the one described during mouse development (Nuttall et al., 2004). However, to date no high expression levels have been reported in mice testis. This suggests that MMP-25 may be differentially expressed between species, or more likely, MMP-25 may be related to spermatogenesis, since Nuttall and co-workers limited their research to newborn mice. Further studies are clearly needed to address this issue in greater detail. Moreover, we observed high mRNA expression in skeletal muscle, suggesting, as it has been reported for MMP-14 (Haas et al., 2000), an active role of MMP-25 in muscular physiology and angiogenesis. Clearly, this issue also needs further detailed studies.

Virtually no studies have concentrated specifically on MMP-27, and scarce general data are available so far. We found MMP27 mRNA to be highly expressed in bone and kidney, and lower expression levels in the heart and a few other tissues. The high expression levels in bone are to some degree in line with findings in human cartilage, where high expression has been reported and implicated in osteogenesis (Kevorkian et al., 2004). During mouse development MMP-27 has been found at low levels in many tissues except the CNS (Nuttall et al., 2004). Similarly, we could only barely detect MMP-27 mRNA in spinal cord, brainstem, cerebellum, cortex, and forebrain of the rat.

MMP-28 was first described from human lung (Marchenko and Strongin,
2001) and human testis cDNA libraries (Lohi et al., 2001). Similarly, in rat we were able to detect highest mRNA expression levels in lung. In contrast, testis showed only a limited expression. This finding underscores the species preservation in mice, since our observations in rat perfectly mirror reports in mice (Illmann et al., 2003). Moreover, bone and kidney in rat contained high MMP-28 mRNA expression levels.

It does not appear surprising that bone was a tissue with consistently high mRNA expression levels for all MMPs studied. The combination of an active osteogenesis, with the ECM being continuously renewed and reshaped, and the presence in the bone marrow of hematopoietic stem cells, which constantly produce all the proteolyticly well-equipped leukocyte progenies, makes this a tissue with one of the relatively largest occurrences of proteases within any organism (Werb and Chin, 1998). Similarly in kidney, the fast renewal of basement membrane in glomerular architecture requires constant proteolytic activity (Schnaper, 1995), which may account for the presence of MMPs in this tissue compartment.

In the present study we investigated the tissue mRNA expression patterns of four newly described MMPs in Lewis rat. The general pattern we defined appears in large parts similar, but not identical, to the one described in mouse and highlights some major differences from the expression and distribution pattern in human. Our findings underscore species differences with respect to these proteases and emphasize the need to take such discrepancies into account before transferring knowledge obtained in an animal model to human.

\section{ACKNOWLEDGEMENTS}

We would like to thank Dr. C. Stephan for his support in designing the primers and molecular biology techniques. This research has been supported by a Marie Curie Fellowship of the European Community Programme for Quality of Life (QLGA-CT2001-52006; to F.B.). 


\section{REFERENCES}

CLARK HF, GURNEY AL, ABAYA E, BAKER K, BALDWIN D, BRUSH J, CHEN J, CHOW B, CHUI C, CROWLEY C, CURRELL B, DEUEL B, DOWD P, EATON D, FOSTER J, GRIMALDI C, GU Q, HASS PE, HELDENS S, HUANG A, KIM HS, KLIMOWSKI L, JIN Y, JOHNSON S, LEE J, LEWIS L, LIAO D, MARK M, ROBBIE E, SÁNCHEZ C, SCHOENFELD J, SESHAGIRI S, SIMMONS L, SINGH J, SMITH V, STINSON J, VAGTS A, VANDLEN R, WATANABE C, WIEAND D, WOODS K, XIE MH, YANSURA D, YI S, YU G, YUAN J, ZHANG M, ZHANG Z, GODDARD A, WOOD WI, GODOWSKI P, GRAY A (2003) The secreted protein discovery initiative (SPDI), a large-scale effort to identify novel human secreted and transmembrane proteins: a bioinformatics assessment. Genome Res 13: 2765-2770

HAAS TL, MILKIEWICZ M, DAVIS SJ, ZHOU AL, EGGINTON S, BROWN MD, MADRI JA, HUDLICKA O (2000) Matrix metalloproteinase activity is required for activity-induced angiogenesis in rat skeletal muscle. Am J Physiol Heart Circ Physiol 279: H1540-1547

HAYASHITA-KINOH H, KINOH H, OKADA A, KOMORI K, ITOH Y, CHIBA T, KAJITA M, YANA I, SEIKI M (2001) Membrane-type 5 matrix metalloproteinase is expressed in differentiated neurons and regulates axonal growth. Cell Growth Differ 12: $573-580$

ILLMAN SA, KESKI-OJA J, PARKS WC, LOHI J (2003) The mouse matrix metalloproteinase, epilysin (MMP28 ), is alternatively spliced and processed by a furinlike proprotein convertase. Biochem J 375: 191-197

JAWORSKI DM (2000) Developmental regulation of membrane type-5 matrix metalloproteinase (MT5MMP) expression in the rat nervous system. Brain Res 860: 174-177

KEVORKIAN L, YOUNG DA, DARRAH C, DONELL ST, SHEPSTONE L, PORTER S, BROCKBANK SM, EDWARDS DR, PARKER AE, CLARK IM (2004) Expression profiling of metalloproteinases and their inhibitors in cartilage. Arthritis Rheum 50: 131-141

KOJIMA S, ITOH Y, MATSUMOTO S, MASUHO Y, SEIKI M (2000) Membrane-type 6 matrix metalloproteinase (MT6-MMP, MMP-25) is the second glycosyl-phosphatidyl inositol (GPI)-anchored MMP. FEBS Lett 480: 142-146

LOHI J, WILSON CL, ROBY JD, PARKS WC (2001) Epilysin, a novel human matrix metalloproteinase (MMP-28) expressed in testis and keratinocytes and in response to injury. J Biol Chem 276: 10134-10144

LLANO E, PENDÁS AM, NAKANO A, KNÄUPER V,
MURPHY G, LÓPEZ-OTÍN C (1999) Identification and characterization of human MT5-MMP, a new membrane-bound activator of progelatinase A overexpressed in brain tumors. Cancer Res 59: 25702576

MARCHENKO GN, STRONGIN AY (2001) MMP-28, a new human matrix metalloproteinase with an unusual cysteine-switch sequence is widely expressed in tumors. Gene 265: 87-93

NAGASE H, WOESSNER JF JR (1999) Matrix metalloproteinases. J Biol Chem 274: 21491-21494

NUTTALL RK, SAMPIERI CL, PENNINGTON CJ, GILL SE, SCHULTZ GA, EDWARDS DR (2004) Expression analysis of the entire MMP and TIMP gene families during mouse tissue development. FEBS Letts 563: 129-134

PEI D (1999) Leukolysin/MMP25/MT6-MMP: a novel matrix metalloproteinase specifically expressed in the leukocyte lineage. Cell Res 9: 291-303

PUENTE XS, LÓPEZ-OTÍN C (2004) A genomic analysis of rat proteases and protease inhibitors. Genome Res 14: 609-622

ROMANIC AM, BURNS-KURTIS CL, AO Z, ARLETH AJ, OHLSTEIN EH (2001) Upregulated expression of human membrane type-5 matrix metalloproteinase in kidneys from diabetic patients. Am J Physiol Renal Physiol 281: F309-F317

SCHNAPER HW (1995) Balance between matrix synthesis and degradation: a determinant of glomerulosclerosis. Pediatr Nephrol 9: 104-111

SEKINE-AIZAWA Y, HAMA E, WATANABE K, TSUBUKI S, KANAI-AZUMA M, KANAI Y, ARAI H, AIZAWA H, IWATA N, SAIDO TC (2001) Matrix metalloproteinase (MMP) system in brain: identification and characterization of brain-specific MMP highly expressed in cerebellum. Eur J Neurosc 13: $935-948$

VELASCO G, CAL S, MERLOS-SUÁREZ A, FERRANDO AA, ÁLVAREZ S, NAKANO A, ARRIBAS J, LÓPEZ-OTÍN C (2000) Human MT6matrix metalloproteinase: identification, progelatinase A activation, and expression in brain tumors. Cancer Res 60: 877-882

WANG X, PEI D (2001) Shedding of membrane type matrix metalloproteinase 5 by a furin-type convertase: a potential mechanism for down-regulation. J Biol Chem 276: 35953-35960

WERB Z, CHIN JR (1998) Extracellular matrix remodelling during morphogenesis. Ann NY Acad Sci 857: $110-118$

YONG VW, POWER C, FORSYTH P, EDWARDS DR (2001) Metalloproteinases in biology and pathology of the nervous system. Nat Rev Neurosc 2: 502-511 